\title{
PERBEDAAN HASIL BELAJAR SISWA YANG DIAJAR DENGAN MENGGUNAKAN MODEL PEMBELAJARAN KOOPERATIF TIPE TEAMS GAMES TOURNAMENT DAN TIPE THINK PAIR SHARE
}

\author{
Laura Sarasonia Sinaga ${ }^{1}$, Waminton Rajagukguk ${ }^{2}$ \\ ${ }^{1,2)}$ Pendidikan Matematika FMIPA Unimed Medan \\ Email: Laurasarasoniasinaga@ gmail.com
}

\begin{abstract}
ABSTRAK
Penelitian ini bertujuan untuk mengetahui perbedaan hasil belajar yang diajarkan dengan menggunakan modle pembelajaran kooperatif tipe TGT dengan hasil belajar yang diajarkan menggunakan model pembelajaran kooperatif tipe TPS pada materi Kubus dan Balok,siswa kelas VIII SMP N 2 Kotapinang T.A 2017/2018.Populasi penelitian ini adalah seluruh kelas VIII SMP N 2 Kotapinang yang terdiri dari 7 kelas. Jenis penelitian ini adalah eksperimen semu dengan instrumen berupa tes pilihan berganda yang telah valid dan reliabilitas tinggi yaitu 0,739 untuk soal pretest dan 0,988 untuk soal postest. Dari hasil analisis data pretest kelas eksperimen I diperoleh $L_{0}=$ $0,142<L_{\text {tabel }}=0,148$ dan data pretest kelas eksperimen II diperoleh $L_{0}=0,134<L_{\text {tabel }}=$ 0,148. Maka dapat disimpulkan data pretest kedua kelas adalah berdistribusi normaL.Dari uji homogenitas data postest diperoleh bahwa kedua sampel homogen yaitu dengan $F_{\text {hitung }}=1,028<F_{\text {tabel }}=1$,76. Setelah dilakukan uji hipotesis dengan uji $t$ maka diperoleh $t_{\text {hitung }}=1,766$ dan $t_{\text {tabel }}=1,666$. Hal ini berarti $t_{\text {hitung }}>t_{\text {tabel }}$ maka $H_{a}$ diterima dan $\mathrm{H}_{0}$ ditolak. Maka dapat disimpulkan bahwa hasil belajar siswa yang diajar dengan model pembelajaran kooperatif tipe TGT lebih tinggi dari hasil belajar siswa yang diajarkan dengan model pembelajaran kooperatif tipe TPS siswa kelas VIII SMP N 2 Kotapinang.
\end{abstract}

Kata kunci : hasil belajar matematika,model TGT,model TPS

\section{ABSTRACT}

This research aims to finds the difference of mathematics achievement thought by cooperative type of TGT (Teams Games Tournament) and TPS(Think Pair Share) on cube and beam material. The subject of this research is the entire class VIII of the junior high shoool of the school year 2017/2018. The design used in this research is quasi experiments and the data coollection technique is objective test that have been valid and high reliability that is 0,739 for pretest and 0,988 for postest. From the analysis of pretest data of experiment class 1 obtained $L_{0}=0,142<L_{\text {tabel }}=0,148$ and for pretest data of experiment class II obtained $L_{0}=0,134<L_{\text {tabel }}=0,148$. It can be concluded the pretest data of both classes are normally distributed. From the homogenity test of postest data obtained that two homogeneous samples are $F_{\text {hitung }}=1,028<F_{\text {tabel }}=1,76$. After hypothesis testing with $t$ test then obtained $t_{\text {hitung }}=1,766$ dan $t_{\text {tabel }}=1$,666.This meanst $t_{\text {hitung }}>t_{\text {tabel }}$ so $H_{a}$ received dan $H_{0}$ rejected. From this research is concluding that learning result using cooperative type of TGT is significantly better than learning result using cooperative type of TPS in class VIII SMP N 2 Kotapinang.

Keywords: mathematics achievement, cooperative learning model of TGT, cooperative learning model of TPS

Laura Sarasonia Sinaga, Waminton Rajagukguk. Perbedaan Hasil Belajar Siswa yang Diajar dengan Menggunakan Model Pembelajaran Kooperatif TipeTeams Games Tournament dan Tipe Think Pair Share. Jurnal Inspiratif, Vol. 4, No. 2 Agustus 2018. 


\section{PENDAHULUAN}

Ranah pendidikanmerupakan bidang yang tak terpisahkan bagi masa depan suatu bangsa. Pendidikan menjadi sumber dan tujuan kemajuan suatu bangsa. Kemajuan peradaban suatu bangsa sangat ditentukan kualitas pendidikannya. Oleh karena itulah, pendidikan dapat dijadikan sebagai parameter seberapa baik kualitas pembangunan suatu bangsa.

Matematika merupakan salah satu mata pelajaran wajib dalam pendidikan formal dan mengambil peran yang sangat penting dalam dunia pendidikan. Penguasaan matematika menjadi modal atau alat untuk mempelajari mata pelajaran lainnya, seperti fisika, kimia, biologi dan bahkan ilmu sosial. Penguasaan matematika akan memberikan dasar pengetahuan untuk bidang-bidang yang sangat penting, seperti penguasaan Ilmu Pengetahuan dan Teknologi (IPTEK).

Sekalipun demikian, mata pelajaran matematika belum menjadi mata pelajaran yang diminati oleh banyak siswa. Hasil belajar matematika siswa cukup rendah. Menurut Depdiknas (dalam Risqi \& Surya, 2017) bahwa salah satu tujuan pembelajaran matematika di sekolah adalah untuk melatih pola pikir dan penalaran dalam mengambil kesimpulan mengembangkan kemampuan untuk memecahkan masalah, dan mengembangkan kemampuan untuk memberikan informasi atau mengkomunikasikan gagasan melalui lisan, tertulis, gambar, grafik, peta , diagram, dll. Seperti yang dikatakan oleh staf pengajar Fakultas Psikologi UGM bidang Psikologi Pendidikan, Supra Wimbarti menyatakan:: "Matematika adalah salah satu (kalau bukan satu-satunya) mata pelajaran ditingkat sekolah dasar yang paling ditakuti siswa .Matematika merupakan mata pelajaran wajib pada jenjang pendidikan dasar sampai atas di
Indonesia". Data UNESCO menunjukkan, peringkat matematika Indonesia berada di deretan 34 dari 38 negara. Data lain yang menunjukkan rendahnya prestasi matematika siswa Indonesia dapat dilihat dari hasil survei Pusat Statistik Internasional untuk Pendidikan terhadap 41 negara dalam pembelajaran matematika,dimana Indonesia mendapatkan peringkat 39 dibawah Thailand dan Uruguay.

Seiring dengan hal tersebut, hasil wawancara dengan Bapak Sahat Gultom, guru matematika di sekolah SMP Negeri 2 Kotapinang, diperoleh keterangan bahwa kegiatan pembelajaran matematika selama ini masih bersifat teacher oriented. Sekitar $70 \%$ pembelajaran masih berpusat pada guru. Guru lebih banyak menjelaskan dan memberikan informasi tentang konsep-konsep yang akan dibahas.Menurut beliau hal itu dikarenakan kemampuan dasar matematika yang dimiliki anak masih rendah.

Selain model pembelajaran teacher oriented yang biasa digunakan guru dalam kegiatan belajar mengajar juga sering ditemukan siswa yang tidak mau bertanya kepada guru. Demikian sebaliknya, apabila guru bertanya, banyak siswa yang tidak dapat menjawab pertanyaan yang diajarkan guru. Adanya kecenderungan bahwa kegiatan pembelajaran terpusat pada guru (teacher centered) siswa hanya mendengar penjelasan dari guru kemudian menulis penjelasan tersebut dari papan tulis. Guru menggunakan metode diskusi konvensional saja terkadang kurang berhasil, karena hanya sedikit siswa yang aktif dan dapat serius belajar dalam kelompok, sedangkan siswa lainnya kebanyakan bertindak pasif, hanya menunggu hasil kerja temannya yang aktif belajar.

Untuk itu guru perlu menciptakan suasana belajar dimana siswa mendapatkan kesempatan 
berinteraksi satu sama lain. Salah satu usaha guru untuk mencapai tujuan pembelajaran adalah dengan menerapkan model pembelajaran yang tepat sehingga proses pembelajaran dapat berjalan efektif dan kondusif.

Salah satu model pembelajaran yang berkembang saat ini adalah pembelajaran kooperatif,model pembelajaran yang dapat melibatkan siswa secara aktif. Hal ini sesuai dengan pendapat Rahmatun dkk (2014) bahwa "Model pembelajaran kooperatif dapat meningkatkan hasil belajar siswa". Hasil belajar merupakan dasar untuk menentukan tingkat keberhasilan siswa dalam memahami materi pelajaran. Hasil belajar adalah kemampuankemampuan yang dimiliki siswa setelah ia menerima pengalaman belajarnya.

Ada beberapa tipe pembelajaran kooperatif, di antaranya adalah model pembelajaran kooperatiftipe TGT (TeamsGames Tournament) dan model pembelajaran tipe TPS (Think Pair and Share).

Model pembelajaran tipe TGT terdiriatas lima komponen utama yaitu presentasi di kelas, tim, game, turnamen, dan rekognisitim. Dalam pelaksanaanya ,siswa dibagi dalam beberapa kelompok untuk berdiskusi memecahkan persoalan yang diberikan. Selainitu, siswa dituntut untuk bersaing dalam memainkan game akademik bersama dengan anggota tim lain untuk menyumbangkan poin bagiskor timasalnya. Sehingga terdapat kompetisi antar kelompok yang di kemas dalam suatu permainan yang menjadikan siswa aktif dalam pembelajaran dan keterlibatan siswa dalam memecahkan persoalan memberi peluang untuk menambah pemahaman siswa, sehingga memungkinkan hasil belajar siswa menjadilebihbaik.Menurut Yanti dkk (2014) Teams Games Tournament dapat menjadikan siswa merasa lebih tertangtang dan semangat untuk mempelajari matematika sehingga melatih kemandirian belajar siswa.

Model pembelajaran tipe TPS terdiri dari tiga komponen utama yaitu berpikir (Thinking), Berpasangan (Pairing) dan Berbagi (Sharing). Dalam pelaksanaannya guru memberikan tugas kepada semua kelompok setelah menyampaikan materi pembelajaran. Setiap siswa memikirkan dan mengerjakan tugas tersebut secara sendiri. Kemudian siswa mendiskusikan jawaban tersebut secara berpasangan untuk menetapkan hasil akhir diskusi kelompok. Setelah siswa berdiskusi beberapa siswa mempresentasikan hasil kerja kelompoknya didepan kelas. Menurut Rahmatun dkk (2014) Think Pair Share ini dapat mengembangkan potensi yang ada pada siswa secara aktif .

Salah satu prinsip dalam pembelajaran kooperatif adalah tanggung jawab individual yang berarti setiap individu memiliki tanggung jawab yang sama dalam menentukan kesuksesan kelompok. Disinilah letak perbedaan model pembelajaran TGT dengan TPS. Pada model pembelajaran TGT ,tanggung jawab individual lebih ditekankan diakhir yaitu pada tahap game tournament setelah siswa berdiskusi dalam kelompok sedangkan pada model TPS,tanggung jawab individual lebih ditekankan diawal yaitu pada tahap think sebelum siswa berdiskusi dalam kelompok.

\section{TINJAUAN PUSTAKA}

Rendahnya hasil belajar matematika siswa antara lain disebabkan masih banyaknya siswa yang menganggap matematika adalah pelajaran yang sulit dan menakutkan. Selain itu kemampuan guru yang masih kurang dalam membangkitkan ketertarikan siswa terhadap matematika juga turut mempengaruhinya. Siswa menjadi kurang antusias dalam mengikuti proses belajar mengajar. 
Bahkan sering dijumpai adanya kecenderungan siswa yang tidak mau bertanya kepada guru meskipun mereka sebenarnya belum mengerti tentang materi yang disampaikan.Tetapi ketika guru menanyakan bagian mana yang belum mereka mengerti seringkali siswa hanya diam, dan setelah guru memberikan soal latihan barulah guru mengerti bahwa sebenarnya ada bagian dari materi yang belum dimengerti siswa.

Hasil belajar mempunyai peranan penting dalam proses pembelajaran. Proses penilaian terhadap hasil belajar dapat memberikan informasi kepada guru tentang kemajuan siswa dalam upaya mencapai tujuantujuan belajarnya melalui kegiatan belajar.Menurut Nitko (dalam Asmin 2014:1) Penilaian adalah suatu istilah yang didefinisikan sebagai suatu proses untuk mendapatkan informasi yang digunakan dalam pengambilan keputusan terhadap siswa,kurikulum dan program serta kebijakan pendidikan.Selanjutnya dari informasi tersebut guru dapat menyusun dan membina kegiatan-kegiatan siswa lebih lanjut, baik untuk keseluruhan kelas maupun individu.

Menurut Sujdana (2009:22) bahwa hasil belajar adalah kemampuankemampuan yang dimiliki siswa setelah ia menerima pengalaman belajarnya. Sedangkan menurut Winkel Hasil belajar adalah perubahan yang menyebabkan manusia mengubah tingkah lakunya. Dari uraian di atas dapat disimpulkan bahwa hasil belajar adalah perubahan yang terjadi dalam diri seseorang yang ditempuh melalui usaha belajar.

Menurut Shoimin (2014:45) Pembelajaran kooperatif adalah model pembelajaran yang mana siswa belajar dalam kelompok-kelompok kecil yang memiliki tingkat kemampuan berbeda. Menurut Slavin (dalam Isjoni 2011:12) pembelajaran kooperatif adalah suatu model pembelajaran dimana siswa belajar dan bekerja dalam kelompokkelompok kecil secara kolaboratif yang anggotanya 4-6 orang dengan struktur kelompok heterogen.

Sedangkan Sunal dan Hans (dalam isjoni 2011:13) mengemukakan pembelajaran kooperatif adalah suatu cara pendekatan atau serangkaian strategi yang khusus dirancang untuk memberi dorongan kepada peserta didik agar bekerja sama selama proses pembelajaran.

Model pembelajaran ini memungkinkan siswa untuk mengembangkan pengetahuan, kemampuan dan keterampilannya secara penuh dalam suasana belajar yang terbuka dan demokratis. Siswa bukan lagi sebagai objek pembelajaran ,namun juga berperan sebagai tutor bagi teman sebayanya.

Pembelajaran kooperatif disusun dalam sebuah usaha untuk meningkatkan partisipasi siswa, memfasilitasi siswa dengan pengalaman sikap kepemimpinan dan membuat keputusan dalam kelompok, serta memberikan kesempatan pada siswa untuk berinteraksi dan belajar bersamasama siswa yang berbeda latar belakangnya.

Dalam pembelajaran kooperatif terdapat sejumlah teknik atau tipe, yang dapat digunakan dalam pembelajaran. Salah satu dari tipe pembelajaran kooperatif itu adalah Teams Games Tournament (TGT) dan Think Pair Share (TPS).

Model pembelajaran tipe Teams Games Tournament melibatkan aktivitas seluruh siswa tanpa harus ada perbedaan status,melibatkan peran siswa sebagai tutor sebaya dan mengandung unsur permainan . Pembelajaran kooperatif model Teams Games Tournament memungkinkan siswa dapat belajar lebih rileks disamping menumbuhkan rasa tanggung jawab ,kerjasama, persaingan sehat dan keterlibatan belajar. Pada 
model ini siswa dkelompokkan dalam kelompok belajar dengan anggota 3-5 orang siswa yang anggotanya heterogen dilihat dari prestasi akademik, jenis kelamin dan ras atau etnik. siswa juga dibentuk dalam kelompok belajar yang heterogen. Siswa mendiskusikan materi dan soal-soal yang diberikan sampai semua anggota dalam kelompok tersebut benar-benar memahaminya. Sehingga siswa dilatih keterampilan-keterampilan untuk membantu sesamanya dan bekerja sama dengan baik. Setelah itu masingmasing siswa dihadapkan pada suatu turnamen melawan anggota-anggota dari kelompok lain dengan kemampuan yang homogen untuk berlomba mendapatkan poin untuk kelompoknya.

Model pembelajaran tipe Think Pair Share memperkenalkan ide :"waktu berpikir atau waktu tunggu" yang menjadi faktor kuat dalam meningkatkan kemampuan siswa dalam merespon pertanyaan. Pembelaaran kooperatif model Think Pair Share ini relatif lebih sederhana karna tidak menyita waktu yang lama untuk mengatur tempat duduk ataupun mengelompokkan siswa. Pada model ini siswa dibentuk dalam kelompok belajar heterogen dan mendiskusikan materi ataupun soal yang diberikan di dalam kelompoknya masing-masing. Guru meminta kepada siswa untuk berpasangan dan mulai memikirkan pertanyaan atau masalah yang diberikan guru dalam waktu tertentu.Lamanya waktu ditetapkan berdasarkan pemahaman guru terhadap siswanya,sifat pertanyaannya dan jadwal pembelajaran. Lalu siswa secara individu mewakili kelompok atau berpasangan melaporkan hasil diskusinya ke depan kelas .

Pelaksanaan pembelajaran dengan menggunakan model pembelajaran kooperatif tipe Teams Games Tournament (TGT) diharapkan dapat memberi hasil yang lebih tinggi dibandingkan dengan menggunakan model pembelajaran kooperatif tipe Think Pair Share (TPS). Dikatakan demikian sebab dalam model pembelajaran Teams Games Tournament dapat melatih pola interaksi dan kerjasama siswa secara baik dan bertanggung jawab, bersikap kompetitif dan sosial. Sedangkan dalam model pembelajaran kooperatif tipe Think Pair Share (TPS) dapat memberi siswa waktu lebih banyak untuk berpikir,lebih mudah dalam menentukan kelompoknya,dapat mengembangkan keterampilan berpikir tetapi dalam diskusi adakalanya hanya sedikit ide yang muncul, menggantungkan diri pada pasangan dan sangat memerlukan kemampuan dan keterampilan guru saat waktu pembelajaran berlangsung guru melakukan intervensi secara maksimal.

\section{METODE PENELITIAN}

Penelitian ini dilaksanakan di SMP NEGERI 2 Kotapinang, waktu penelitian ini dilaksanakan pada semester II Tahun Ajaran 2017/ 2018. Dengan alasan bahwa sekolah ini belum pernah dilakukan penelitian yang sejenis. Populasi dalam penelitian ini adalah seluruh siswa kelas VIII yang berjumlah 7 kelas.Dari 7 kelas pararel diambil 2 kelas secara random dengan sistem undi. Satu kelas dijadikan kelas eksperimen I yaitu kelas VIII-1 yang berjumlah 36 diajarkan dengan model kooperatif tipe Teams Games Tournament dan satu kelas dijadikan kelas eksperimen II yaitu kelas VIII-2 yang berjumlah 36 diajarkan dengan model kooperatif tipe Think Pair Share.

Jenis penelitian ini adalah penelitian eksperimen semu.Penelitian ini melibatkan dua kelas yaitu kelas eksperimen I dan kelas eksperimen II yang diberi perlakuan berbeda. Pada kelas eksperimen I diberikan perlakuan yaitu pengajaran materi kubus dan balok dengan menggunakan model kooperatif tipe TGT sedangkan pada kelas eksperimen II diberi perlakuan yaitu

Laura Sarasonia Sinaga, Waminton Rajagukguk. Perbedaan Hasil Belajar Siswa yang Diajar dengan Menggunakan Model Pembelajaran Kooperatif TipeTeams Games Tournament dan Tipe Think Pair Share. Jurnal Inspiratif, Vol. 4, No. 2 Agustus 2018. 
pengajaran materi kubus dan balok dengan menggunakan model kooperatif tipe TPS.Untuk mengetahui hasil belajar siswa maka pertama memberikan pretest kepada kedua kelas untuk mengukur kemampuan awal yang terhadap materi yang diajarkan sebagai dasar pengelompokan. Lalu Memberikan postest kepada kedua kelas untuk mengukur tingkat penguasaan terhadap materi yang telah diajarkan. Dan melakukan uji hipotesis hasil belajar siswa dengan menggunakan uji $t$ untuk menentukan apakah perbedaan skornya signifikan yaitu perbedaan yang cukup besar untuk menolak hipotesis nol.

\section{HASIL PENELITIAN DAN PEMBAHASAN}

Sebelum diberikan pembelajaran yang berbeda yaitu pembelajaran dengan tipe Teams Games Tournament (TGT) untuk kelas eksperimen I dan tipe Think Pair Share (TPS) untuk kelas eksperimen II , kedua kelas diberikan tes awal (Pretest) untuk mengetahui kemampuan awal matematika siswa. Hasil pemberian pretest pada kelas eksperimen I adalah 57,04 sedangkan skor rata-rata pretest pada kelas eksperimen II adalah 54,07.
Tabel 1. Data Kemampuan Awal Siswa

\begin{tabular}{|c|c|c|}
\hline & $\begin{array}{c}\text { Eksperimen } \\
\mathrm{I}\end{array}$ & Eksperimen 2 \\
\hline $\mathrm{N}$ & 36 & 36 \\
\hline Rata-Rata & 57,04 & 54,07 \\
\hline $\begin{array}{c}\text { Standar } \\
\text { Deviasi }\end{array}$ & 10,50 & 10,54 \\
\hline Varians & 110,33 & 111,17 \\
\hline $\begin{array}{c}\text { Nilai } \\
\text { Minimum }\end{array}$ & 40,00 & 40,00 \\
\hline $\begin{array}{c}\text { Nilai } \\
\text { Maksimum }\end{array}$ & 73,33 & 73,33 \\
\hline
\end{tabular}

Setelah diberikan pembelajaran yang berbeda yaitu pembelajaran dengan tipe Teams Games Tournment (TGT) untuk kelas eksperimen I dan pembelajaran dengan tipe Think Pair Share (TPS) untuk kelas eksperimen II ,maka kedua kelas diberikan tes akhir (Postest) untuk mengetahui kemampuan matematika siswa setelah diberikan pembelajaran. Hasil pemberian postest pada kelas eksperimen I diperoleh ratarata 78,15 dan pada kelas eksperimen II diperoleh rata-rata 73,70 . Secara ringkas hasil postest kedua kelas diperlihatkan pada tabel berikut ini :

Tabel 2.Data Hasil Belajar Siswa

\begin{tabular}{|c|c|c|}
\hline & Eksperimen I & Eksperimen 2 \\
\hline $\mathrm{N}$ & 36 & 36 \\
\hline Rata-Rata & 78,15 & 54,07 \\
\hline Standar Deviasi & 10,88 & 11,53 \\
\hline Varians & 118,37 & 121,76 \\
\hline Nilai Minimum & 60,00 & 60,00 \\
\hline Nilai Maksimum & 93,33 & 93,33 \\
\hline
\end{tabular}

Sebelum dilakukan pengujian terhadap hipotesis, terlebih dahulu menguji normalitas dan homogenitas. Pengujian normalitas data dilakukan dengan uji lilifors,setelah dilakukan uji normalitas yang terdapat di lampiran,maka hasilnya dapat dilihat pada tabel dibawah ini :

Laura Sarasonia Sinaga, Waminton Rajagukguk. Perbedaan Hasil Belajar Siswa yang Diajar dengan Menggunakan Model Pembelajaran Kooperatif TipeTeams Games Tournament dan Tipe Think Pair Share. Jurnal Inspiratif, Vol. 4, No. 2 Agustus 2018. 
Tabel 3. Ringkasan Hasil Uji Normalitas Data Hasil Belajar

\begin{tabular}{|c|c|c|c|c|c|c|}
\hline \multirow{2}{*}{ Kelas } & \multicolumn{3}{|c|}{ Pretest } & \multicolumn{3}{c|}{ Postest } \\
\cline { 2 - 7 } & $\mathbf{L}_{\text {hitung }}$ & $\mathbf{L}_{\text {tabel }}$ & Ket & L $_{\text {hitung }}$ & $\mathbf{L}_{\text {tabel }}$ & Ket \\
\hline Eks. I & 0,142 & 0,148 & Normal & 0,143 & 0,148 & Normal \\
\hline Eks. II & 0,134 & 0,148 & Normal & 0,140 & 0,148 & Normal \\
\hline
\end{tabular}

Berdasarkan tabel diatas diperoleh bahwa $\mathrm{L}_{0}<\mathrm{L}_{\text {hitung }}$. Dengan demikian dapat disimpulka bahwa data pretest dan postest kedua kelas berasal dari populasi yang berdistribusi normal.

Pengujian homogenitas data untuk mengetahui apakah sampel yang digunakan berasal dari populasi yang homogen atau tidak.Maksudnya apakah sampel yang dipilih dapat mewakili seluruh populasi yang ada atau tidak.
Pengujian homogenitas digunakan uji kesamaan kedua varians yaitu uji F. Jika $\mathrm{F}_{\text {hitung }} \geq \mathrm{F}_{\text {tabel }}$ maka $\mathrm{H}_{0}$ ditolak dan jika $\mathrm{F}_{\text {hitung }}<\mathrm{F}_{\text {tabel }}$, maka $\mathrm{H}_{0}$ diterima. Dengan derajat kebebasan pembilang sebesar $\left(\mathrm{n}_{1}-1\right)$ dan derajat kebebasan penyebut sebesar $\left(\mathrm{n}_{2}-1\right)$ dengan taraf nyata $\alpha=0,05$. Ringkasan hasil perhitungan uji homogenitas disajikan pada tabel dibawah ini :

Tabel 4. Data Uji Homogenitas

\begin{tabular}{|c|c|c|c|c|c|}
\hline Data & $\begin{array}{c}\text { Varians } \\
\text { Terbesar }\end{array}$ & $\begin{array}{c}\text { Varians } \\
\text { Terkecil }\end{array}$ & $\mathbf{F}_{\text {hitung }}$ & $\mathbf{F}_{\text {tabel }}$ & Ket \\
\hline Pretest & 111,1743 & 110,3265 & 1,007 & 1,76 & Homogen \\
\hline Postest & 121,7612 & 118,3722 & 1,028 & 1,76 & Homogen \\
\hline
\end{tabular}

Dari tabel dilihat bahwa $\mathrm{F}_{\text {hitung }}<\mathrm{F}_{\text {tabel }}$ pada taraf nyata $\alpha=0,05$ yang berarti kedua sampel memiliki varians yang homogen

Kemudian dilakukan pengujian hipotesis dengan menggunakan uji-t. Pertama menguji Hipotesis Pretest.

$\mathrm{H}_{0} \quad: \mu_{1}=\mu_{2}$

$\mathrm{H}_{\mathrm{a}} \quad: \mu_{1} \neq \mu_{2}$

Keterangan :

$\mu_{1}=$ Rata-rata kemampuan awal siswa yang diajar dengan model pembelajaran kooperatif tipe Teams Games Tournament. $\mu_{1}=$ Rata-rata kemampuan awal siswa yang diajar dengan model pembelajaran kooperatif tipe Think Pair Share.

Pengujian ini menggunakan uji- $t$ ,syaratnya:

$\mathrm{H}_{0}$ diterima jika harga $\mathrm{t}_{\text {hitung }}<\mathrm{t}_{\text {tabel }}$ dan $\mathrm{H}_{\mathrm{a}}$ ditolak pada taraf nyata $\alpha=0,05$

$\mathrm{H}_{\mathrm{a}}$ diterima jika harga $\mathrm{t}_{\text {thitung }}>\mathrm{t}_{\text {tabel }}$ dan $\mathrm{H}_{0}$ ditolak pada taraf nyata $\alpha=0,05$

$\mathrm{d}_{\mathrm{k}}=\mathrm{n}_{1}+\mathrm{n}_{2}-2$

Ringkasan hasil uji hipotesis pretest dapat dilihat pada tabel dibawah ini. 
Tabel 5.Perhitungan Uji Hipotesis Pretes

\begin{tabular}{|c|c|c|c|c|c|}
\hline \multirow{2}{*}{ Data } & \multicolumn{2}{|c|}{$\bar{X}$} & $\mathrm{t}_{\text {hitung }}$ & $\mathrm{t}_{\text {tabel }}$ & Ket \\
\cline { 2 - 3 } & Eksperimen I & Eksperimen II & & & \\
\hline Postest & 57,04 & 54,07 & 1,227 & 1,995 & $\mathrm{H}_{0}$ diterima \\
\hline
\end{tabular}

Bedasarkan perhitungan diperoleh harga $t_{\text {hitung }}=1,227$ kemudian dikonsultasikan dengan daerah kritis diperoleh $\mathrm{t}_{\text {hitung }}<\mathrm{t}_{\text {tabel }}$ yatu 1,227 $<1,995$. Maka dapat disimpulkan $\mathrm{H}_{0}$ diterima dan $\mathrm{H}_{\mathrm{a}}$ ditolak yan berarti tidak ada perbedaan kemampuan awal siswa dikedua kelas.

Setelah itu menguji hipotesis postest

$\mathrm{H}_{0} \quad: \mu_{1} \leq \mu_{2}$

$\mathrm{H}_{\mathrm{a}} \quad: \mu_{1}>\mu_{2}$

Keterangan :

$\mu_{1}=$ Rata-rata kemampuan awal siswa yang diajar dengan model pembelajaran kooperatif tipe

Teams Games Tournament.

$\mu_{1}=$ Rata-rata kemampuan awal siswa yang diajar dengan model pembelajaran kooperatif tipe Think Pair Share.

Pengujian ini menggunakan ujit,syaratnya:

$\mathrm{H}_{0}$ diterima jika harga $\mathrm{t}_{\text {hitung }}<\mathrm{t}_{\text {tabel }}$ dan $\mathrm{H}_{\mathrm{a}}$ ditolak pada taraf nyata $\alpha=0,05$

$\mathrm{H}_{\mathrm{a}}$ diterima jika harga $\mathrm{t}_{\text {thitung }}>\mathrm{t}_{\text {tabel }}$ dan

$\mathrm{H}_{0}$ ditolak pada taraf nyata $\alpha=0,05$

$\mathrm{d}_{\mathrm{k}}=\mathrm{n}_{1}+\mathrm{n}_{2}-2$

Ringkasan hasil uji hipotesis pretest dapat dilihat pada tabel dibawah ini.

Tabel 6.Perhitungan Uji Hipotesis Postest

\begin{tabular}{|c|c|c|c|c|c|}
\hline Data & \multicolumn{2}{|c|}{$\bar{X}$} & \multirow{2}{*}{$\mathrm{t}_{\text {hitung }}$} & $\mathrm{t}_{\text {tabel }}$ & Ket \\
\cline { 2 - 3 } & Eksperimen I & Eksperimen II & & & \\
\hline Postest & 78,15 & 73,70 & 1,766 & 1,666 & $\mathrm{H}_{0}$ ditolak \\
\hline
\end{tabular}

Bedasarkan perhitungan diperoleh harga $t_{\text {hitung }}=1,766$ kemudian dikonsultasikan dengan daerah kritis diperoleh $t_{\text {hitung }}>t_{\text {tabelyatu }} 1,766<$ 1,666.Karna $t_{\text {hitung }}$ berada pada daerah kritis maka $\mathrm{H}_{0}$ ditolak atau $\mathrm{H}_{\mathrm{a}}$ diterima.

Maka dapat disimpulkan hasil belajar siswa yang diajarkan dengan model pembelajaran kooperatif tipe Teams Games Tournament (TGT) lebih tinggi dari hasil belajar siswa yang diajarkan dengan model pembelajaran kooperatif tipe Think Pair Share (TPS).

Untuk memperkuat hasil penelitian, peneliti membandingkan hasil penelitian ini juga diperkuat dengan penelitian yang dilakukan penelitian oleh Tiya(2013) terhadap siswa kelas VIII pada materi sistem persamaan linier dua variabel dengan judul "Penerapan model pembelajaran kooperatif tipe Teams Games Tournament (TGT) dalam upaya meningkatkan hasil belajar mahasiswa SMP Negeri 1 Mawasangka”. Setelah pemberian tindakan pada siklus I diperoleh nilai $\geq 60$ sebanyak 15 orang siswa atau sebesar $46,88 \%$ dengan nilai rata-rata 60,47 telah mencapai tingkat ketuntasan belajar. Lalu diberikan tindakan pada siklus II diperoleh siswa yang memperoleh nilai $\geq 60$ sebanyak 22 orang atau sebesar $68,75 \%$ dengan nilai rata-rata 62,33 .Ini berarti bahwa hasil belajar matematika siswa dari siklus I ke siklus II mengalami peningkatan dari hasil evaluasi

Laura Sarasonia Sinaga, Waminton Rajagukguk. Perbedaan Hasil Belajar Siswa yang Diajar dengan Menggunakan Model Pembelajaran Kooperatif TipeTeams Games Tournament dan Tipe Think Pair Share. Jurnal Inspiratif, Vol. 4, No. 2 Agustus 2018. 
sebelumnya. Selanjutnya peneliti melanjutkan siklus III dan diperoleh nilai $\geq 60$ sebanyak 28 orang siswa atau sebesar $87,5 \%$ dengan nilai rata-rata 80,46 . Ini berarti bahwa hasil belajar matematika siswa dan kemampuan memecahkan masalah matematika setiap siklus mengalami peningkatan dilihat dari hasil belajarnya. Dari tindakan dan analisa yang dilakukan dapat disimpulkan bahwa penerapan model TGT pada pokok bahasan persamaan linier dua variabel dapat menuntaskan hasil belajar siswa. Kemampuan memecahkan masalah adalah salah satu prinsip utama ilmu pengetahuan dan teknologi serta dalam mengajar penting untuk kemajuan pendidikan matematika itu sendiri. Pinter (dalam Simamora et al., 2017) menyatakan bahwa kemampuan menyelesaikan masalah adalah keterampilan yang sangat penting. Dengan kemampuan memecahkan masalah matematika siswa akan dapat mengatur situasi kehidupan nyata dalam model matematika. Kemampuan pemecahan masalah itu sendiri bukan hanya tujuan dalam belajar matematika, tetapi juga sesuatu yang sangat berarti dalam kehidupan sehari-hari, dan dalam dunia kerja, menjadi pemecah masalah dapat memberikan manfaat atau keuntungan.

Penelitian yang sama juga telah dilakukan oleh Surya, Putri, dan Mukhtar juga menemukan pada penelitiannya menunjukkan bahwa (1) kemampuan pemecahan masalah matematika siswa yang diajarkan dengan model pembelajaran kontekstual (situasi kehidupan nyata) lebih tinggi daripada siswa yang diajarkan oleh ekspositori, (2) terdapat interaksi antara model pembelajaran dan kemampuan awal matematika siswa untuk meningkatkan kemampuan pemecahan masalah matematika siswa.
Penelitian yang serupa juga dilakukan oleh Listyawati dkk (2015) terhadap siswa kelas VIII pada materi pemfaktoran bentuk aljabar dengan judul : "Penerapan model pembelajaran Kooperatif tipe Think Pair Share untuk meningkatkan hasil belajar siswa pada materi pemfaktoran bentuk aljabar dikelas VIII SMPN 20 PALU'. Setelah diberikan tindakan pada siklus I siswa yang tuntas atau memperoleh nilai $\geq 70$ sebanyak 10 orang siswa dari 24 siswa yang mengikuti tes, dengan persentase ketuntasan klasikal sebesar 61,54\%. Sedangkan, pada siklus II, siswa yang tuntas atau memperoleh nilai $\geq 70$ sebanyak 20 orang siswa dari 26 siswa yang mengikuti tes, dengan persentase ketuntasan klasikal sebesar 76,92\% .Ini berarti bahwa hasil belajar matematika siswa setiap siklus mengalami peningkatan dilihat dari hasil belajarnya. Dari tindakan dan analisa yang dilakukan dapat disimpulkan bahwa penerapan model Think Pair Share pada pokok bahasan pemfaktoran bentuk aljabar dapat menuntaskan hasil belajar siswa.

Berdasarkan perbandingan dari penelitian yang terdahulu dengan penelitian yang dilakukan sekarang menunjukkan bahwa model pembelajaran kooperatif tipe TGT dan TPS keduanya dapat meningkatkan hasil belajar siswa dengan kondisi hasil belajar model TGT lebih baik dari model TPS. Hal ini disebabkan karena model pembelajaran kooperatif tipe TGT cenderung lebih mengedepankan penerimaan terhadap individu,proses belajar mengajar berlangsung dengan persaingan yang seimbang karena pada saat turnamen, siswa dikelompokkan dengan teman yang memiliki kemampuan yang sama,mendidik siswa untuk berlatih bersosialisasi dengan yang lain dan menuntut rasa tanggung jawab siswa untuk berbuat yang terbaik buat kelompoknya. Sedangkan pada

Laura Sarasonia Sinaga, Waminton Rajagukguk. Perbedaan Hasil Belajar Siswa yang Diajar dengan Menggunakan Model Pembelajaran Kooperatif TipeTeams Games Tournament dan Tipe Think Pair Share. Jurnal Inspiratif, Vol. 4, No. 2 Agustus 2018. 
model pembelajaran TPS, lebih sedikit ide yang muncul,menggantungkan diri pada pasangan dan banyak siswa yang bingung sehingga sebagian kehilangan kepercayaan diri dan saling mengganggu antar siswa.

Meskipun pembelajaran kooperatif tipe TGT lebih mampu meningkatkan hasil belajar siswa lebih baik dari tipe TPS, selama berlangsungnya proses pembelajaran dalam penelitian ini,peneliti juga

\section{KESIMPULAN DAN SARAN}

Berdasarkan hasil penelitian dan pembahasan yang telah diuraikan,maka dapat disimpulkan Terdapat perbedaan hasil belajar siswa yang diajar menggunakan model pembelajaran kooperatif tipe Teams Games Tournament dengan model pembelajaran kooperatif tipe Think Pair Share di Kelas VIII SMPN 2 Kotapinang dan Hasil belajar siswa dengan menggunakan model pembelajaran kooperatif tipe Teams Games Tournament lebih tinggi darihasil belajar siswa yang diajarkan dengan model pembelajaran kooperatif tipe Think Pair Share dikelas VIII SMPN 2 Kotapinang dengan rata-rata hasil belajar siswa yang diajar dengan menggunakan model pembelajaran kooperatif tipe Teams Games Tournament adalah $\bar{X}=78,15$ dan standard deviasi adalah 10,88 ,sedangkan rata-rata hasil belajar

\section{DAFTAR PUSTAKA}

Annisa, dkk, (2014), Pengaruh Pembelajaran Kooperatif Tipe Teams Games Tournament Terhadap Hasil Belajar Matematika Di Kelas VIII Smpn 2 Bukittinggi T.A 2013/2014,Jurnal, FMIPA, UNP, Vol. 3 No. 1. menemukan beberapa kelemahan model pembelajaran kooperatif tipe TGT,yaitu:

1. Waktu yang dihabiskan siswa untuk diskusi cukup banyak sehingga siswa melewati waktu yang sudah ditetapkan.

2. Adanya kemungkinan terjadi kegaduhan kalau guru tidak dapat mengelola kelas.

siswa yang diajar dengan menggunakan model pembelajaran kooperatif tipe Think Pair Share adalah $\bar{X}=73,70$ dan standard deviasi adalah 11,03.

Adapun saran yang dapat diberikan peneliti dari hasil penelitian ini adalah:Dalam menerapkan model pembelajaran Teams Games Tournament (TGT) dan Think Pair Share (TPS),pendidik atau mahasiswa dan calon guru terlebih dahulu harus memiliki persiapan matang untuk melaksanakan proses pembelajaran; dan Jika dihadapkan dengan pilihan menggunakan model pembelajaran kooperatif tipe Teams Games Tournament (TGT) dan Think Pair Share (TPS),maka guru disarankan memilih model pembelajaran TGT untuk meningkatkan hasil belajar siswa.

Arikunto, S. (2016),Manajemen Penelitian,Rineka Cipta,Jakarta.

Asmin, (2014). Pengukuran dan Penilaian Hasil Belajar Dengan Analisis Klasik dan Modern, Larispa Indonesia,Medan.

Laura Sarasonia Sinaga, Waminton Rajagukguk. Perbedaan Hasil Belajar Siswa yang Diajar dengan Menggunakan Model Pembelajaran Kooperatif TipeTeams Games Tournament dan Tipe Think Pair Share. Jurnal Inspiratif, Vol. 4, No. 2 Agustus 2018. 
Hamalik, O. (2014),Proses Belajar Mengajar,Bumi Aksara,Jakarta.

Hasratuddin. (2015), Mengapa Harus Belajar Matematika, Perdana Publishing,Medan.

Isjoni, (2011). Cooperative Learning, Alfabeta, Bandung.

Listyawati, dkk. (2013), Penerapan Model Pembelajaran Kooperatif Tipe Think Pair Share Untuk Meningkatkan Hasil Belajar Siswa Pada Materi Pemfaktoran Bentuk Aljabar Di Kelas VIII Smpn 20 Palu, Skripsi, FMIPA, Universitas Tadulako.

Rahmatun. dkk, 2014),Penerapan Pembelajaran Kooperatif Tipe Think Pair Share Pada Pembelajaran Matematika Di Kelas XI IPS SMA Negeri 2 Padang Panjang, Jurnal, FMIPA ,UNP, Vol. 3 No. 1.

Rizqi, N. R., \& Surya, E. 2017. An Analysis of Students' Mathematical Reasoning Ability In VIII Grade of Sabilina Tembung Junior High School. International Journal of Advance Research And Innovative Ideas In Education (IJARIIE). Vol-3 Issue-2 2017.

Shoimin, Aris. (2016), Model Pembelajaran Inovatif dalam Kurikulum 2013, Ar-ruzz Media, Yogyakarta.

Simamora, R. E., Sidabutar, D. R ., \& Surya, E. 2017. Improving Learning Activity and Students' Problem Solving Skill through Problem Based Learning (PBL) In Junior High School. International Journal of Sciences: Basic and Applied
Research (IJSBAR). Volume 33, No 2, pp (321-331).

Slameto, (2016). Belajar dan Faktor Yang Mempengaruhi, Rineka Cipta, Jakarta.

Sudjana, N. (2009), Penilaian Hasil Proses Belajar Mengajar,Bumu Aksara,Jakarta.

Surya, E. (2017). Efek Think Pair Share Dalam Meningkatkan Kemampuan Pemecahan Masalah Siswa SMP ,FMIPA,UNIMED. http://www.researchgate.net/publi cation/321831307 diakses tanggal 02 Maret 2017.

Surya, E., Putri, F.A.,\& Mukhtar. 2017. Improving Mathematical Problem-Solving Ability And Self-Confidence Of High School Students Through Contextual Learning Model. Journal on Mathematics Education. Volume 8, No. 1, pp. (85-94).

Tya, Kadir. (2013). Penerapan Model Pembelajaran Kooperatif Tipe Teams Games Tournament (TGT) dalam Upaya Meningkatkan Hasil Belajar Matematika Siswa SMPN 1 Mawasangka, Jurnal, FMIPA, Universitas Haluoleo, Volume 4 nomor 2.

Widuri, dkk, (2013). ,Perbedaan Efektivitas Model Kooperatif Tipe TPS dan TGT Terhadap Hasil Belajar Matematika Tentang Pecahan Pada Siswa Kelas V SD Negeri 1 Sidoharum Tahun Ajaran 2012/2013, Jurnal, FKIP, UNS. 